Dokuz Eylül Üniversitesi-Mühendislik Fakültesi Fen ve Mühendislik Dergisi

Cilt 20, Sayı 59, Mayıs, 2018
Dokuz Eylul University-Faculty of Engineering Journal of Science and Engineering Volume 20, Issue 59, May, 2018

\title{
Boyalı Suların Çitosan Koagülasyonu ile Arıtımında Box-Wilson İstatistiksel Tasarım Yönteminin Kullanılması
}

\section{Ezgi OKTAV AKDEMIR}

Dokuz Eylül Üniversitesi, Mühendislik Fakültesi, Çevre Mühendisliği. Bölümü, 35160, İzmir (ORCID:0000-0001-9513-3524).

(Alınış / Received: 09.11.2017, Kabul / Accepted: 19.03.2018, Online Yayınlanma / Published Online: 15.05.2018)

Anahtar Kelimeler Özet: Tekstil endüstrisi atıksularındaki en önemli kirletici kaynakları Box-Wilson proseste kullanılan boyalardır. Bu çalışmada, boyalı sulardan renk ve İstatistiksel Tasarım Yöntemi, Boya, Çitosan, Koagülasyonflokülasyon. KOİ giderimi amacıyla çitosan ile koagülasyon yöntemi uygulanmıştır. Deneysel çalışmalarda Box Wilson istatistiksel tasarım yöntemi kullanılmış, boya konsantrasyonu, çitosan konsantrasyonu ve koagülasyon-flokülasyon sonrası çökelme süresinin renk ve KOİ giderme verimi üzerindeki etkileri incelenmiștir. Boya konsantrasyonu 50-200 mg/l, çitosan konsantrasyonu 50-200 mg/l ve çökelme süresi 30-120 dakika aralığında seçilmiştir. En yüksek renk giderme veriminin (\%70) elde edildiği boya konsantrasyonu $50 \mathrm{mg} / \mathrm{l}$, çitosan konsantrasyonu $125 \mathrm{mg} / \mathrm{l}$ ve çökelme süresi 90 dakika olarak belirlenmiștir. KOİ giderimi incelendiğinde ise $200 \mathrm{mg} / \mathrm{l}$ boya konsantrasyonu, $200 \mathrm{mg} / \mathrm{l}$ çitosan konsantrasyonu ve 30 dakika çökelme süresinde en yüksek KOİ giderme verimi (\%60) elde edilmiștir.

\section{The Use of Box-Wilson Statistical Design Method in the Treatment of Dyeing Wastewaters with Chitosan Coagulation}

\begin{tabular}{ll}
\hline Keywords & Abstract: The most important pollutant sources in the textile industry \\
Box-Wilson & wastewater are the dyes used in the process. In this study, coagulation \\
Statistical & method with chitosan was applied for color and COD removal from \\
Design Method, & dyeing wastewater. In the experimental studies, the Box Wilson \\
Dye, & statistical design method was used and the effects of dye concentration, \\
Chitosan, & chitosan concentration and precipitation time after coagulation- \\
Caogulation- & flocculation on color and COD removal efficiency were investigated. \\
floculation & The dye concentration was selected to be $50-200 \mathrm{mg} / \mathrm{l}$, chitosan \\
& concentration $50-200 \mathrm{mg} / \mathrm{l}$ and precipitation time $30-120$ minutes. The \\
& highest color removal efficiency $(70 \%)$ was determined as $50 \mathrm{mg} / \mathrm{l}$ of \\
& dye concentration, $125 \mathrm{mg} / \mathrm{l}$ of chitosan concentration and $90 \mathrm{minutes}$ \\
& of precipitation time. When the COD removal was examined, the \\
& highest COD removal efficiency $(60 \%)$ was obtained at $200 \mathrm{mg} / \mathrm{l}$ of dye \\
& concentration, $200 \mathrm{mg} / \mathrm{l}$ of chitosan concentration and $30 \mathrm{minutes}$ of \\
& precipitation time.
\end{tabular}

*Sorumlu yazar: ezgi.oktav@deu.edu.tr 


\section{Giriş}

Günümüzde önemli çevre kirletici kaynaklarının bașında endüstriler gelmektedir. Tekstil endüstrisi de dünyada yaygın olarak bulunan önemli endüstrilerden biridir. Yüksek miktarda su tüketimi ve üretimde kullanılan boyalar, biyosidler, deterjanlar gibi birçok üründen dolayı değişen atıksu karakteristikleri nedeniyle tekstil atıksularının arıtımı önemli çevre sorunları arasında yer almaktadır [1]. Dünya genelinde yaklaşık 10.000 farklı ticari boya ile pigment mevcuttur ve yılda 70.000 ton civarı üretim yapılmaktadır. $\mathrm{Bu}$ boyaların yaklașık \% 10-15'inin boyama ișlemleri sırasında atık olarak bırakıldığı tahmin edilmektedir. Boya üretim endüstrisi ve tekstil endüstrisi gibi boya ve pigmentleri kullanan diğer birçok sanayiden açığa çıkan atıksularda hem renk hem de organik madde içeriği yüksektir [2]. Bu atıksular, yüksek konsantrasyonlarda boyar madde, surfaktan, kompleks yapıda inorganik ve organik bileşikler nedeniyle karmaşık bir yapıdadır. Boyar maddeler zor ayrışabilir olduğundan arıtımı da zor olmaktadır [3].

Boyalı sulardan renk giderimi amacıyla çoğunlukla kullanılan yöntemler adsorpsiyon, kimyasal ve foto oksidasyon ve kimyasal arıtma yöntemleridir [4]. Koagülasyon, flokülasyon ve çökelme süreçlerinden oluşan kimyasal arıtma yöntemi bu tür suların arıtımında ön arıtım, nihai arıtım ya da bazı durumlarda tam arıtım amaciyla kullanılabilir. $\mathrm{Bu}$ yöntem düşük maliyetlidir, uygulanması kolaydır ve alternatif arıtma yöntemlerine klyasla daha az enerji tüketir [5]. Renk giderimi amacıyla yapilan kimyasal arıtma yönteminde en çok kullanılan kimyasallar arasinda $\mathrm{FeCl}_{3}, \mathrm{FeSO}_{4}$, $\mathrm{Al}_{2}\left(\mathrm{SO}_{4}\right)_{3}$ bulunmaktadır [6]. Son yıllarda yapılan çalışmalarda çevre dostu koagülantların atıksu arıtımında uygulanabilirliği araştırılmaktadır. Biyolojik olarak parçalanabilen, toksik olmayan bir doğal polimer olarak çitosan, boyalı sulardan renk giderimi amaciyla kullanılmaktadır $[4,7]$.

Kongo Kırmızı boyasının doğal koagülantlarla arıtımının incelendiği bir çalışmada koagülant olarak çitosan, surjana tohumu ve mısır kullanılmıştır. Her üç koagülant için de optimum doz 25 $\mathrm{mg} / \mathrm{l}$ olarak bulunmuş, bu durumda elde edilen renk giderme verimleri çitosan, surjana tohumu ve mısır için sırasıyla $\% 75, \% 68$ ve $\% 55$ olmuştur [1].

Bir anyonik boya olan Asit Mavi 92'nin (AB92) çitosan koagülasyonu ile gideriminin araștırıldığı bir çalışmada boya konsantrasyonu 25-100 mg/l, çitosan konsantrasyonu ise $20-150 \mathrm{mg} / \mathrm{l}$ aralığında alınmıştır. Düşük boya ve çitosan konsantrasyonlarında \%99'a varan renk giderme verimleri elde edilmiştir [8].

Asif v.d. tarafından yapılan bir çalışmada tekstil atıksularının arıtımında koagulant olarak çitosan kullanılmıştır. $18 \mathrm{mg} / \mathrm{l}$ çitosanın optimum doz olarak belirlendiği çalıșmada \%98 TKM, $\% 87$ renk ve $\% 71$ KOİ giderme verimleri elde edilmiştir [9].

$\mathrm{Bu}$ çalışmanın amacı, biyolojik polimer olan çitosanı koagülant olarak kullanarak boyalı sulardan renk ve KOİ giderimini araştırmaktır. Deneysel çalışmalarda farklı boya ve çitosan konsantrasyonlarında hızlı karıștırma (koagülasyon), yavaş karıştırma (flokülasyon) ve çökeltim süreçlerinden oluşan jar testi deneyleri yapılmıştır. Box Wilson istatistiksel deney tasarım yöntemi kullanılarak boya konsantrasyonu, çitosan konsantrasyonu ve koagülasyon-flokülasyon sonrası çökelme süresinin renk ve KOİ giderme verimi üzerindeki etkileri incelenmiştir. 
Giderme verimlerini en iyi hale getiren boya ve çitosan konsantrasyonları ve çökelme süreleri belirlenerek çalışma kapsamında sunulmuştur.

\section{Materyal ve Metot}

\section{1.} deneyleri

\section{Koagülasyon-flokülasyon}

Deneysel çalışmalarda kullanılan laboratuvar ölçekli jar testi düzeneği, Velp Scientifica firmasından JLT 6 modeli olarak temin edilmiş ve Şekil 1'de gösterilmiştir. Deneylerin başında belirlenen boya ve çitosan dozları hassas terazide tartılarak $500 \mathrm{ml}$ 'lik beherlere alınmıș ve üzerlerine saf su eklenmiștir. Önce 200 rpm karıştırma hızında 3 dakika hızlı karıștırma, sonra $25 \mathrm{rpm}$ karıştırma hızında 45 dakika yavaş karıştırma işlemi uygulanmıştır. Karıștırma ișlemi bitince numuneler önceden belirlenen sürelerde çökelme işlemine tabi tutulmuştur. Çökelme işlemi sonunda beherlerin üst kısmından pipet yardımı ile örnekler alınarak renk ve KOİ analizleri yapılmıştır. Renk ölçümleri HACH Lange marka DR 5000 model spektrofotometrede 456 nanometre dalga boyunda yapılmıştır. KOİ analizi ise Standart Metodlar'a göre yapılmıştır [10].

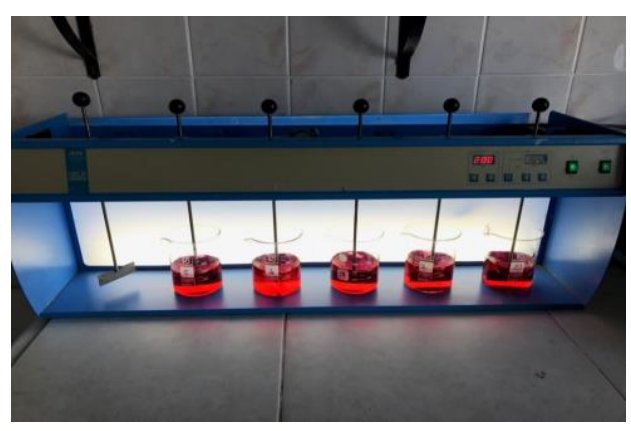

Şekil 1. Jar testi düzeneği

\section{2. Çitosan ve boya}

Deneysel çalışmalarda kullanılan ve biyolojik katyonik bir polimer olan çitosan yüksek molekül ağırlığına sahiptir. Sigma-Aldrich firmasindan 419419 ürün koduyla elde edilmiştir. Çitosanın genel kimyasal yapısı Şekil 2'de verilmektedir.

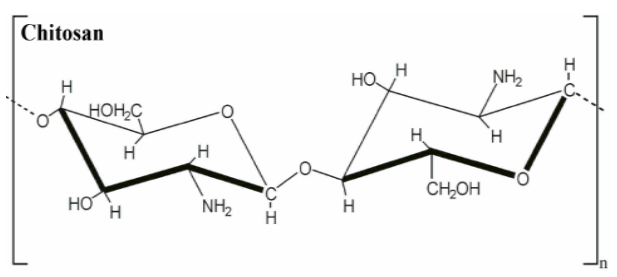

Şekil 2. Çitosanın genel kimyasal yapısı [11]

Asit kırmızı 95 (AR95) boyası ise tekstil endüstrisinde sıkça kullanılan bir boyadır ve İzmir ili torbalı ilçesinde bulunan bir tekstil firmasından temin edilmiştir. Boyanın genel karakteristik özellikleri Tablo 1'de verilmektedir. Maksimum absorbansın elde edildiği dalga boyu, laboratuarda yapılan dalga boyu taraması sonucu $456 \mathrm{~nm}$ olarak bulunmuştur. Boyanın KOI'sini hesaplamak için yapılan analizler sonucunda, $1 \mathrm{mg}$ boyanın KOI'si $3,25 \mathrm{mg} / \mathrm{l}$ olarak bulunmuştur. 
E.O.Akdemir / Boyalı Suların Çitosan Koagülasyonu ile Arıtımında Box-Wilson İstatistiksel Tasarım Yönteminin Kullanılması

Tablo 1. Asit Kırmızı 95 (AR95) Boyasının Genel Karakteristik Özellikleri [12]

\begin{tabular}{ll}
\hline Asit kırmızı 95 & $\begin{array}{l}\text { Superfix Red 195, } \\
\text { 3BF \%150 } \\
\text { Xanthan sınıfı, asit } \\
\text { bazlı }\end{array}$ \\
Molekül ağırlığı (g/mol) & 1136,32 \\
Molekül formülü
\end{tabular}

\subsection{Box-Wilson deneysel tasarim metodu}

Bu çalışma kapsamında yapılan deneyler Box-Wilson deneysel tasarım metoduna göre tasarlanmıştır. Box-Wilson deneysel tasarımı, fiziksel ve kimyasal süreçlerin matematiksel modellerini türetmek için genel deneyler serisinden oluşan etkin temele dayalı bir yöntemdir. Özellikle endüstriyel uygulamalarda kullanımı ve yararı, seçilen faktörlerin uygun bir aralığında fiziksel durumun kuadratik fonksiyonla tanımlanmasıyla artmaktadır [7].

Box-Wilson deneysel tasarım metodu,

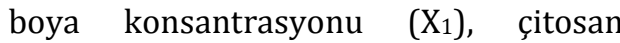
konsantrasyonu $\left(\mathrm{X}_{2}\right)$ ve çökelme süresi $\left(\mathrm{X}_{3}\right)$ parametrelerinin koagülasyonflokülasyon ile renk ve KOİ giderimi üzerindeki etkilerini belirlemek için kullanılmıştır. Boya konsantrasyonu 50-200 mg/l, çitosan konsantrasyonu 50-200 $\mathrm{mg} / \mathrm{l}$ ve çökelme süresi 30-120 dakika aralığında seçilmiştir. Toplamda 16 adet jar testi deneyi yapılmıștır. Renk ve KOİ giderme verimi için Box-Wilson deneysel tasarım metodu bağımsız değișken noktaları Tablo 2'de verilmiştir.

Tablo 2. Box-Wilson deneysel tasarımı için bağımsız değișken noktaları

\begin{tabular}{llll}
\hline Deney numarası & Boya (mg/l) & Çitosan (mg/l) & Zaman (dakika) \\
\hline Aksiyal noktalar & & & \\
A1 & 200 & 125 & 75 \\
A2 & 50 & 125 & 75 \\
A3 & 125 & 200 & 75 \\
A4 & 125 & 50 & 75 \\
A5 & 125 & 125 & 120 \\
A6 & 125 & 125 & 30 \\
Faktöriyal noktalar & & & \\
F1 & 82 & 168 & 101 \\
F2 & 168 & 82 & 101 \\
F3 & 168 & 168 & 49 \\
F4 & 168 & 82 & 49 \\
F5 & 82 & 82 & 101 \\
F6 & 82 & 168 & 49 \\
F7 & 168 & 168 & 101 \\
F8 & 82 & 82 & 49 \\
Merkez nokta & & & 75 \\
C & 125 & 125 & \\
\hline
\end{tabular}


Renk giderme verimi hesabı için aşağıda verilen cevap fonksiyonu kullanılmıștır:

$Y=b_{0}+b_{1} X_{1}+b_{2} X_{2}+b_{3} X_{3}+$

$b_{12} X_{1} X_{2}+b_{13} X_{1} X_{3}+b_{23} X_{2} X_{3}+$

$b_{11} x_{1^{2}}+b_{22} x_{2^{2}}+b_{33} x_{3^{2}}$

Burada

Y: verim,

$\mathrm{b}_{0}$ : sabit,

$\mathrm{b}_{1}, \mathrm{~b}_{2}, \mathrm{~b}_{3}$ : doğrusal katsaylar,

$\mathrm{b}_{12}, \mathrm{~b}_{13}, \mathrm{~b}_{23}$ : çapraz ürün katsayıları,

$\mathrm{b}_{11}, \mathrm{~b}_{22}, \mathrm{~b}_{33}$ ikinci dereceden

katsayılardır.

\section{Bulgular}

\subsection{Box-Wilson deneysel tasarım metodu sonuçları}

Box-Wilson Deneysel Tasarım Metodunda kullanılan cevap fonksiyonu katsayıları Statistica 5.0 bilgisayar programı kullanılarak hesaplanmış ve sonuçlar Tablo 3'de verilmiştir. Cevap fonksiyonu katsayıları ve ișaretleri, bağımsız değişkenin etkisinin yoğunluğunu ve yönünü belirtmektedir. Katsayının pozitif olması (+ işareti) bağımsız değişkenin değeri arttıkça verimin arttığını, katsayının negatif olması ise (- işareti) o bağımsız değişkenin değeri artarken verimin azaldığını göstermektedir.

Cevap fonksiyonu katsayıları incelendiği zaman, renk giderme veriminin çitosan konsantrasyonu ile arttığı, boya konsantrasyonu ve çökelme süresinin artması ile ise azaldığı görülmüştür. KOİ giderimi incelenecek olursa, boya konsantrasyonu ve çitosan konsantrasyonu arttıkça KOİ giderme verimi de artmaktadır. Çökelme süresinin katsayısı diğer katsayılardan mertebe olarak daha küçüktür. Dolayısıyla çökelme süresinin KOİ giderimine etkisi diğer değişkenlere göre daha azdır.
Tablo 3. Renk ve KOİ giderimi için cevap fonksiyonu katsayıları

\begin{tabular}{lll}
\hline $\begin{array}{l}\text { Cevap } \\
\text { fonksiyonu } \\
\text { katsaylları }\end{array}$ & $\begin{array}{l}\text { Renk } \\
\text { giderimi }\end{array}$ & $\begin{array}{l}\text { KOİ } \\
\text { giderimi }\end{array}$ \\
\hline b $_{0}$ & 1,0173341 & 0,164304 \\
b $_{1}$ & $-0,0022576$ & 0,002078 \\
b$_{2}$ & 0,0017842 & 0,002107 \\
b $_{3}$ & $-0,0024292$ & 0,000669 \\
b $_{12}$ & 0,0000060 & $-0,000008$ \\
b $_{13}$ & 0,0000649 & $-0,000002$ \\
b$_{23}$ & $-0,0000031$ & $-0,000002$ \\
b $_{11}$ & $-0,0000269$ & 0,000000 \\
b $_{22}$ & 0,0000078 & $-0,000001$ \\
b $_{33}$ & $-0,0000009$ & 0,000001 \\
\hline
\end{tabular}

Belirlenen katsayılar kullanılarak cevap fonksiyonu ile renk ve KOİ giderme verimi değerleri hesaplanmıştır. Laboratuvar ortamında jar testi ile yapılan çalışmalar sonucunda ölçülmüş değerler ile bilgisayar programı kullanılarak hesaplanan renk ve KOİ giderme verimleri Tablo 4'de verilmektedir.

Tablo 4. Renk ve KOİ giderimi için deneysel olarak belirlenen ve bilgisayar programı kullanılarak hesaplanan değerler

\begin{tabular}{|c|c|c|c|c|}
\hline \multirow{2}{*}{$\begin{array}{l}\text { Deney } \\
\text { no }\end{array}$} & \multicolumn{2}{|c|}{$\begin{array}{c}\text { Renk giderimi } \\
(\%)\end{array}$} & \multicolumn{2}{|c|}{$\begin{array}{l}\text { KOİ giderimi } \\
\text { (\%) }\end{array}$} \\
\hline & $\begin{array}{l}\text { Deney- } \\
\text { sel }\end{array}$ & $\begin{array}{l}\text { Hesapla- } \\
\text { nan }\end{array}$ & $\begin{array}{l}\text { Deney- } \\
\text { sel }\end{array}$ & $\begin{array}{l}\text { Hesapla- } \\
\text { nan }\end{array}$ \\
\hline A1 & 49,0 & 52,1 & 62,0 & 60,7 \\
\hline A2 & 54,0 & 52,6 & 47,0 & 48,8 \\
\hline A3 & 69,0 & 67,0 & 57,0 & 58,8 \\
\hline $\mathrm{A} 4$ & 53,0 & 56,7 & 51,0 & 49,8 \\
\hline A5 & 54,4 & 58,0 & 56,0 & 56,7 \\
\hline A6 & 58,5 & 56,5 & 54,0 & 53,9 \\
\hline F1 & 55,0 & 54,4 & 58,0 & 56,3 \\
\hline F2 & 57,0 & 52,0 & 57,0 & 57,9 \\
\hline F3 & 44,8 & 44,7 & 59,0 & 59,0 \\
\hline F4 & 36,6 & 35,9 & 55,0 & 56,3 \\
\hline F5 & 52,6 & 51,4 & 49,0 & 48,6 \\
\hline F6 & 65,0 & 68,8 & 56,0 & 54,6 \\
\hline F7 & 60,0 & 59,4 & 60,0 & 59,6 \\
\hline F8 & 65,1 & 64,4 & 46,0 & 46,0 \\
\hline $\mathrm{C}$ & 57,9 & 57,5 & 55,0 & 55,0 \\
\hline
\end{tabular}

Renk giderimi için Box-Wilson deneysel tasarım metodu uygulandığı zaman, deneylerde ölçülen renk değerleri ile Statistica programı ile hesaplanan renk değerleri arasındaki korelasyon 
katsayısı $\left(R^{2}\right)$ 0.944, KOİ giderimi için korelasyon katsayısı ise 0.942 olarak ölçülmüştür. Bu da ölçülen ve hesaplanan değerler arasında iyi bir uyum olduğunu göstermektedir.

\subsection{Renk giderimi}

Çökelme süresinin 90 dakikada sabit tutulduğu ilk çalışmada, çitosan ve boya konsantrasyonlarındaki değişimin renk giderme verimine olan etkileri incelenmiş, sonuçlar grafik halinde Şekil 3 'de sunulmuştur. $\mathrm{Bu}$ grafik incelendiğinde, renk giderme veriminin belli bir çitosan konsantrasyonuna kadar artarak maksimum değere ulaştığı, daha sonra da sistematik olarak azaldığı görülmektedir. $\mathrm{Bu}, \quad$ yük nötralizasyon mekanizması tarafından kontrol edilen bir koagülasyonflokülasyon sisteminin tipik eğrisidir. Sülfonik gruplar taşıyan anyonik boya, çitosanın protonlanmış amin grupları tarafından elektrostatik olarak çekilir. $\mathrm{Bu}$ reaksiyon, birlikte bağlanıp çökelebilen boyaların anyonik yüklerini nötralize eder. Protonlanmış amin gruplarının miktarı anyonik yükleri tamamen nötralize ettiğinde, boya giderme verimi maksimuma ulaşır. Çözeltiye ilave edilen çitosan miktarı arttırıldığında, aşırı miktardaki protonlanmış amin grupları çözeltide yeniden stabilize hale gelir ve verimi düşürür [7,13]. En iyi çitosan konsantrasyonu, bütün boyar madde konsantrasyonları için yaklaşık $125 \mathrm{mg} / \mathrm{l}$ olarak bulunmuştur.
Renk giderme veriminin farklı boya konsantrasyonları ile zamanla değişimi Şekil 4'te verilmektedir. Bütün boya konsantrasyonları için renk giderme verimi çökelme süresinin artışıla birlikte artmaktadır. Yaklaşık 90 dakikalık çökelme süresi sonrasında ise verimde bir miktar düşüş olmaktadır. Dolayısıyla en yüksek renk giderme verimlerinin elde edildiği çökelme süresi bütün boya konsantrasyonları için 90 dakika olarak belirlenmiştir. Öte yandan, artan boya konsantrasyonu renk giderme verimini olumsuz yönde etkilemektedir. 90 dakika çökelme süresi için $50 \mathrm{mg} / \mathrm{l}$ boya konsantrasyonunda $\% 70$ renk giderme verimi elde edilirken, aynı sürede 200 $\mathrm{mg} / \mathrm{l}$ boya konsantrasyonu için elde edilen verim \% 53'e düşmektedir. Bu durumda maksimum renk giderme verimi için boya konsantrasyonunun $50 \mathrm{mg} / \mathrm{l}$ olduğu söylenebilir. Reaktif sarı 15 (RY15) boyası ile daha önce yapılmış bir çalışmada artan boya konsantrasyonunun renk giderimini olumsuz etkilediği bulunmuştur. Yine aynı çalışmada çökeltim süresinin artışıyla renk giderme veriminin artığ ancak 80-90 dakikalık çökeltim sürelerinden sonra verimin azaldığ belirtilmiştir [7]. Bu çalışmada bulunan sonuçlar da bunu destekler niteliktedir. 


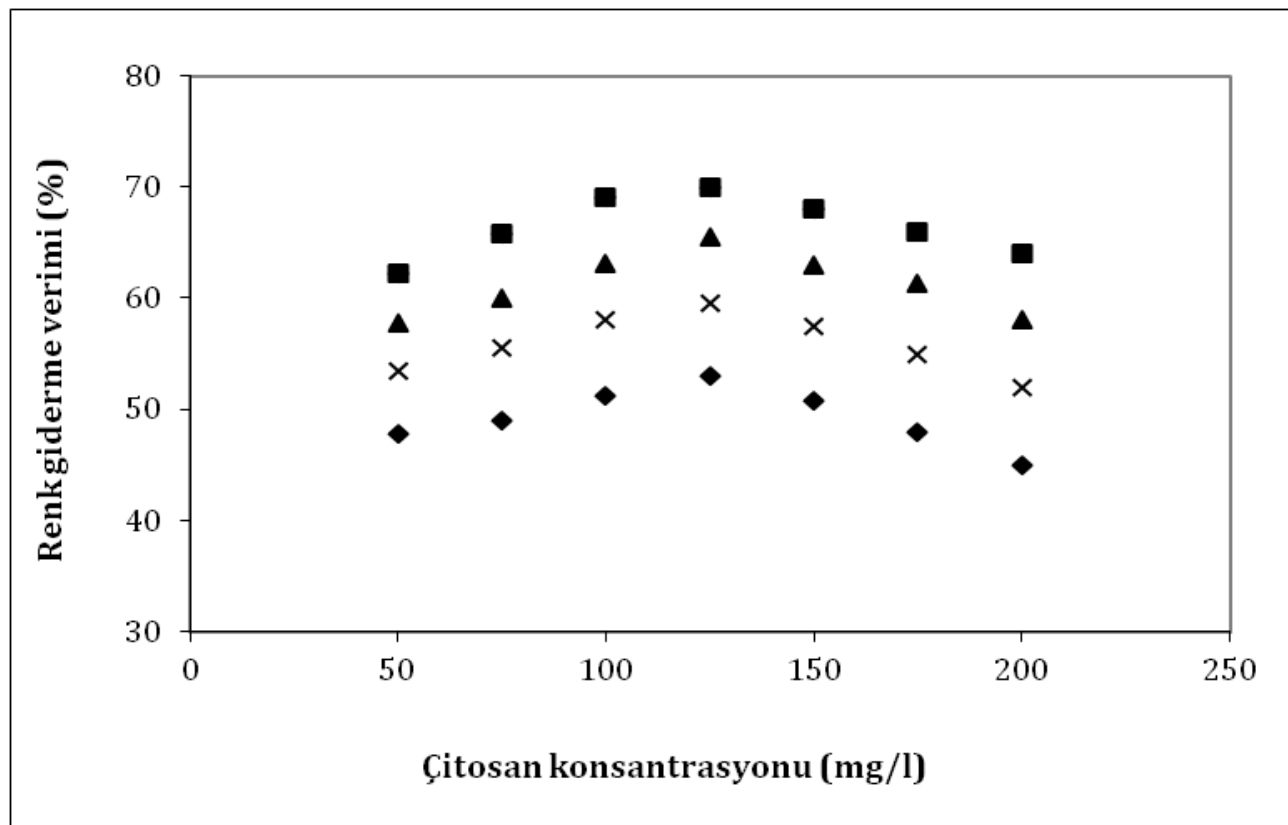

Şekil 3. Renk giderme veriminin çitosan konsantrasyonu ile farklı boya konsantrasyonlarındaki değişimi. (Süre: 90 dakika) Boya konsantrasyonu: (ロ) 50 mg/l, (A) 100 mg/l, (x) $150 \mathrm{mg} / \mathrm{l}$, (•) $200 \mathrm{mg} / \mathrm{l}$

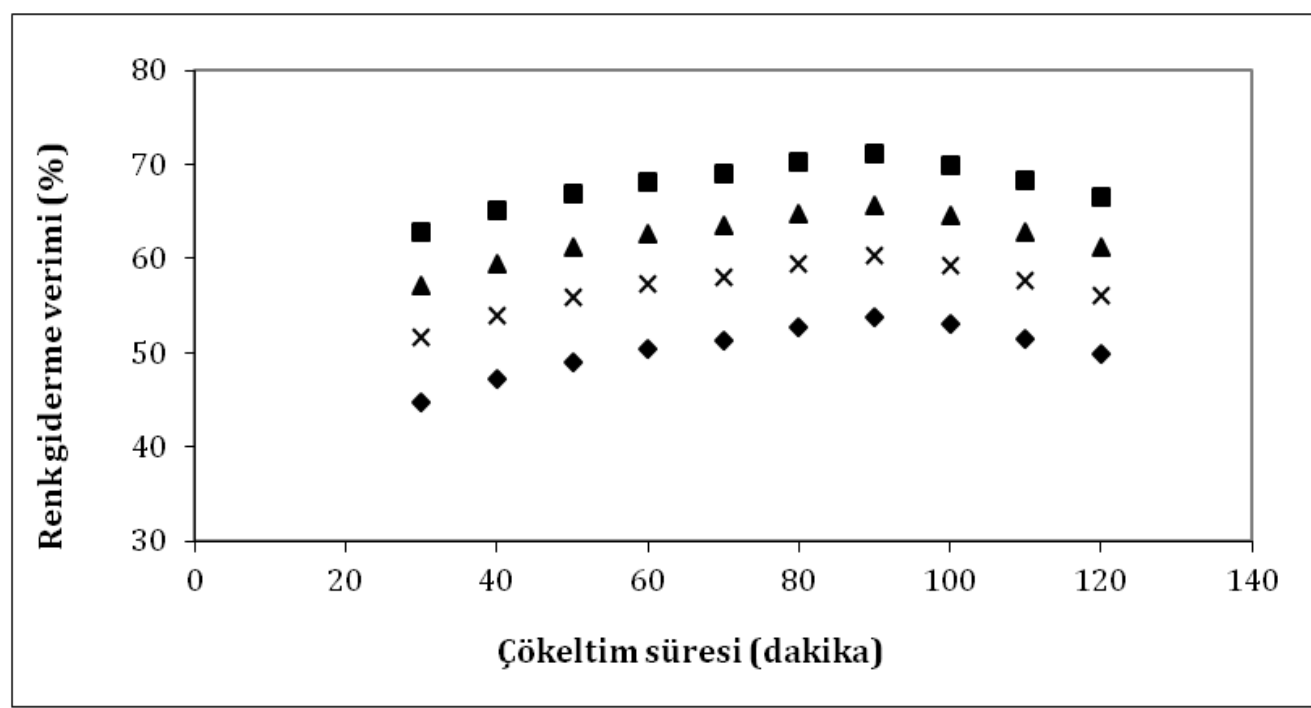

Şekil 4. Renk giderme veriminin farklı boya konsantrasyonları ve farklı çökeltim sürelerinde değişimi. (Çitosan konsantrasyonu:125 mg/l) Boya konsantrasyonu: (ש) $50 \mathrm{mg} / \mathrm{l}$, (A) $100 \mathrm{mg} / \mathrm{l},(\mathrm{x}) 150 \mathrm{mg} / \mathrm{l},(\bullet) 200 \mathrm{mg} / \mathrm{l}$ 


\subsection{KoI giderimi}

Deneysel çalıșmaların ikinci aşamasında boya konsantrasyonu, çitosan konsantrasyonu ve çökelme süresindeki değişimin KOİ giderme verimi üzerindeki etkileri araştırılmıștır. Boya konsantrasyonunun $50 \mathrm{mg} / \mathrm{l}$ 'de sabit tutulduğu ilk çalışmada, artan çitosan konsantrasyonu ve çökelme süresiyle KOİ giderme verimi ilişkisi incelenmiş, sonuçlar Şekil 5'te verilmiştir. Çitosan konsantrasyonundaki ve çökelme süresindeki artış KOİ giderme verimini de arttırmaktadır. 30 dakika çökelme süresi için $50 \quad \mathrm{mg} / \mathrm{l}$ çitosan konsantrasyonunda \% 36 verim varken bu değer $200 \mathrm{mg} / \mathrm{l}$ çitosan konsantrasyonunda $\%$ 56'ya yükselmektedir. Aynı çitosan konsantrasyonları için 120 dakika çökelme süresi uygulandığı zaman KOİ giderme verimleri sirasiyla \% 42 ve $\% 58$ olmaktadır.

Artan çitosan konsantrasyonu ile KOİ giderme veriminin artması yük yoğunluğu olgusu ile açıklanabilir. Çitosan diğer biyolojik polimerlere göre daha yüksek yük yoğunluğuna sahiptir. Artan dozlarda kullanıldığı zaman yük yoğunluğuna bağlı olarak polimerin adsorpsiyonu da artmakta ve böylece boyalı suyun KOİ konsantrasyonu azalarak KOİ giderme verimi artmaktadır [14].

Yapılan son çalıșmada çitosan konsantrasyonu $50 \mathrm{mg} / \mathrm{l}$ 'de sabit tutulmuș, boya konsantrasyonu ve çökelme süresindeki değişimin KOİ giderme verimi üzerindeki etkileri incelenmiştir. Sonuçlar Şekil 6'da verilmektedir. Cökelme süresindeki artışın, özellikle yüksek boya konsantrasyonlarında KOİ giderme verimi üzerinde çok fazla etkisi yoktur. $200 \mathrm{mg} / \mathrm{l}$ boya konsantrasyonunda 30 dakikalık çökelme sonunda hesaplanan verim \% 59 iken, süre 120 dakikaya uzadığı zaman bu verim \% 61 olarak ölçülmüştür. Boya konsantrasyonu $50 \mathrm{mg} / \mathrm{l}$ iken ise aynı sürelerdeki KOİ giderme verimleri sirasiyla $\% 36$ ve $\% 42$ 'dir.

Yapılan bir çalışmada çitosan ile koagülasyon-flokülasyon sonrası çökeltim süresindeki artıșın Toplam Organik Karbon (TOK) giderimi üzerinde çok etkili olmadığı, en yüksek giderme veriminin 30 dakikalık çökeltim süresinde elde edildiği belirtilmiștir [7]. Bu çalıșmada KOİ giderme verimi için de benzer sonuçlar elde edilmiştir.

Öte yandan boya konsantrasyonundaki artış verimi önemli ölçüde artırmaktadır. Bütün çökelme süresi boyunca $\quad 50 \quad \mathrm{mg} / \mathrm{l}$ boya konsantrasyonunda ortalama $\% 39$ verim elde edilirken, boya konsantrasyonu $200 \mathrm{mg} / \mathrm{l}$ 'ye çıktığında ortalama verim $\% 60$ 'a çıkmaktadır. 
E.O.Akdemir / Boyalı Suların Çitosan Koagülasyonu ile Arıtımında Box-Wilson İstatistiksel Tasarım Yönteminin Kullanılması

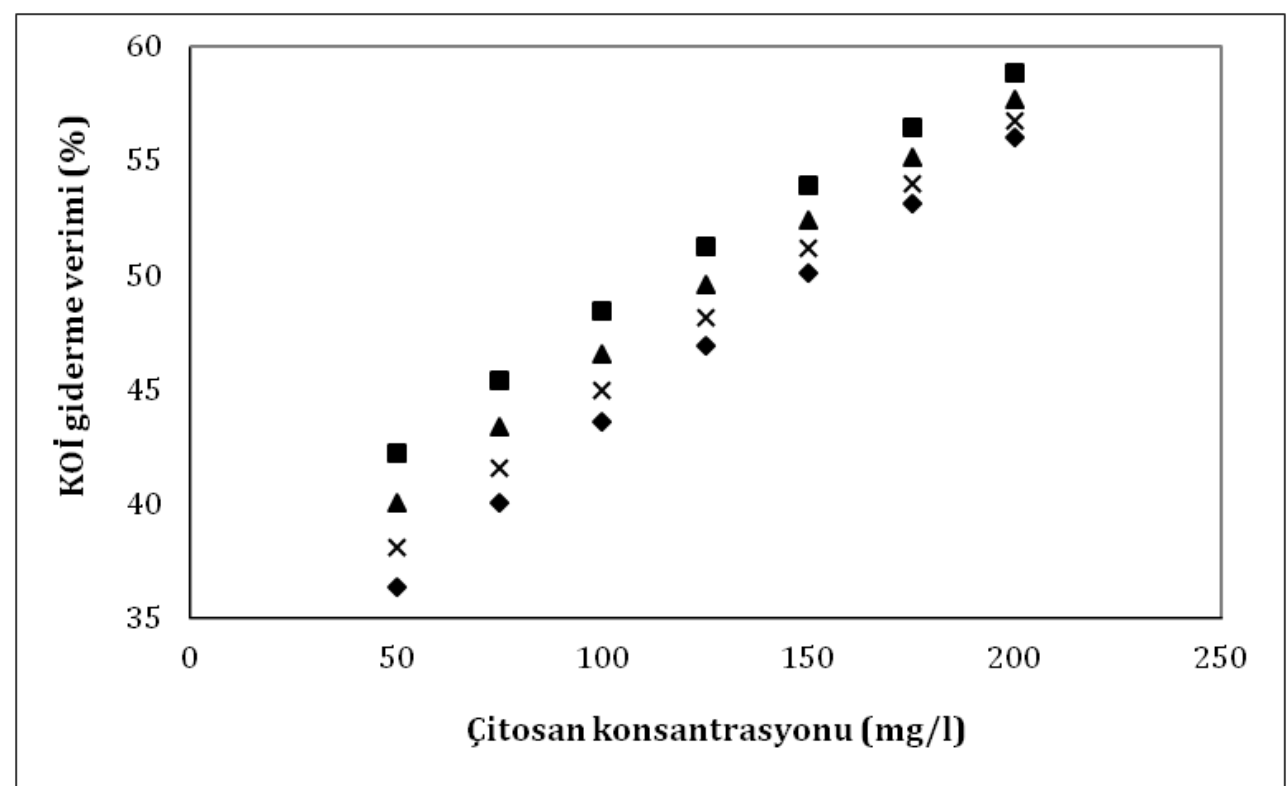

Şekil 5. KOİ giderme veriminin çitosan konsantrasyonu ile farklı çökeltim sürelerindek değișimi (Boya konsantrasyonu: 50 mg/l) Süre: ( $\$ 30$ dak, (x) 60 dak, (४) 90 dak, (ロ) 120 dak.

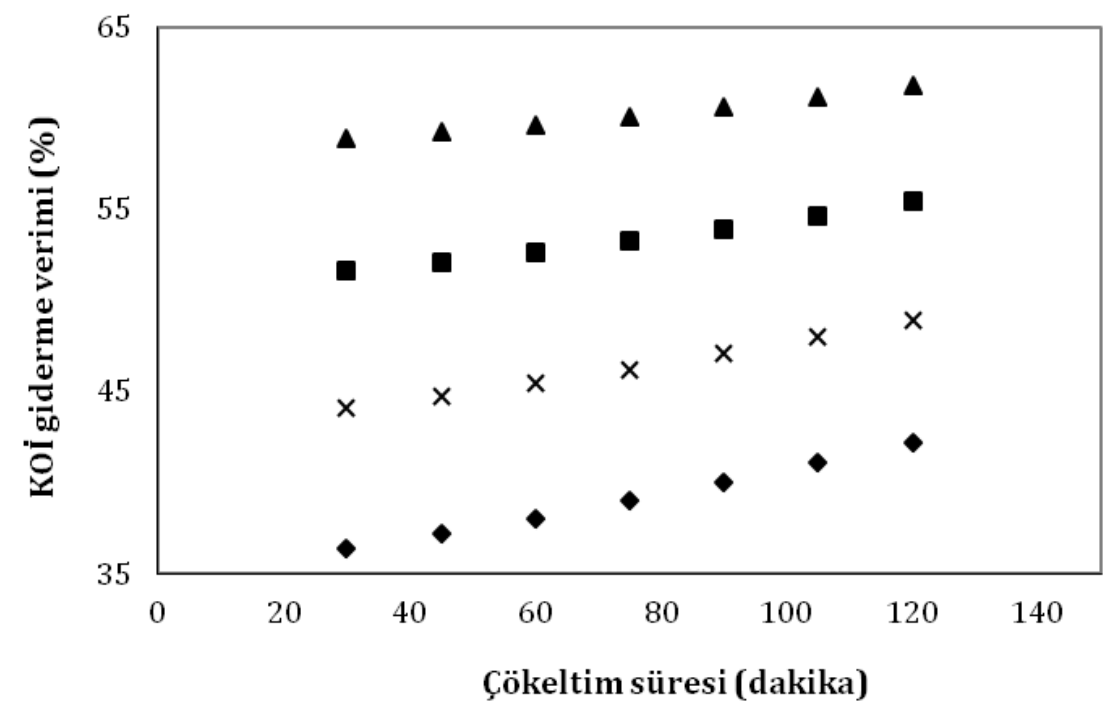

Şekil 6. KOİ giderme veriminin farklı boya konsantrasyonlarında zamanla değişimi. (Çitosan konsantrasyonu:50 mg/l) Boya konsantrasyonu: (») $50 \mathrm{mg} / \mathrm{l},(\mathrm{x}) 100 \mathrm{mg} / \mathrm{l},(\mathbf{m}) 150 \mathrm{mg} / \mathrm{l}$, (A) $200 \mathrm{mg} / \mathrm{l}$. 
Yapılan bütün deneysel çalıșmalar sonunda, koagülasyon ve flokülasyon işlemi ile en yüksek renk ve KOİ giderme verimlerinin sağlandığ optimum çitosan konsantrasyonu ve çökelme süresinin başlangıçtaki boya konsantrasyonuna bağlı olarak değiştiği görülmüștür. Optimum koşullar toplu halde Tablo 5'de sunulmuştur. Maksimum renk giderimi için düşük boya konsantrasyonu ve yüksek çökelme süresi gerekmektedir. Yüksek boya ve çitosan konsantrasyonlarında KOİ giderme verimi artmaktadır. Çökelme süresinin ise KOİ giderme verimine etkisi düşüktür.

Tablo 5. Maksimum giderme verimlerinin elde edildiği boya, çitosan konsantrasyonu ve çökelme süresi değerleri

\begin{tabular}{lllll}
\hline & $\begin{array}{l}\text { Boya } \\
\text { kons. } \\
\mathrm{X}_{1} \\
(\mathrm{mg} / \mathrm{l})\end{array}$ & $\begin{array}{l}\text { Çitosan } \\
\text { kons. } \\
\mathrm{X}_{2}(\mathrm{mg} / \mathrm{l})\end{array}$ & $\begin{array}{l}\text { Çökelme } \\
\text { süresi } \\
\mathrm{X}_{3} \\
\text { (dak) }\end{array}$ & $\begin{array}{l}\text { Verim } \\
(\%)\end{array}$ \\
\hline $\begin{array}{l}\text { Renk } \\
\text { giderimi }\end{array}$ & 50 & 125 & 90 & 70 \\
& & & \\
$\begin{array}{l}\text { KOİ } \\
\text { giderimi }\end{array}$ & 200 & 200 & 30 & 60 \\
\hline
\end{tabular}

Renk giderme verimleri ile KOİ giderme verimleri arasındaki ilişkiyi görmek açısından $50 \mathrm{mg} / \mathrm{l}$ ve $200 \mathrm{mg} / \mathrm{l}$ boya konsantrasyonlarında ve 90 dakika çökeltim süresinde, farklı çitosan konsantrasyonları için renk ve KOİ giderme verimleri incelenmiş, sonuçlar Şekil 7 ve Şekil 8'de verilmiştir. Düşük boya konsantrasyonlarında renk giderme verimi KOİ gideriminden daha yüksektir. Aynı çökeltim süresi ve çitosan konsantrasyonlarında boya konsantrasyonunun artmasıyla KOİ giderimi renk giderme veriminden daha yüksek hale gelmiştir. Patel ve Vashi bir çalışmasında 291Pt-Co renk ve 1556 mg/l KOİye sahip bir tekstil endüstrisi atıksuyuyla çalışmıştır. 50-350 mg/l çitosan konsantrasyonlarında renk giderme verimleri $\% 40$ mertebesindeyken KOİ giderme verimlerinde \%65'lere ulaşılmıştır [15]. Şekil 8'de görüldüğü gibi yüksek boya konsantrasyonuyla yapılan çalışmada Patel ve Vashi'ye yakın sonuçlar elde edilmiştir. 
E.O.Akdemir / Boyalı Suların Çitosan Koagülasyonu ile Arıtımında Box-Wilson İstatistiksel Tasarım Yönteminin Kullanılması

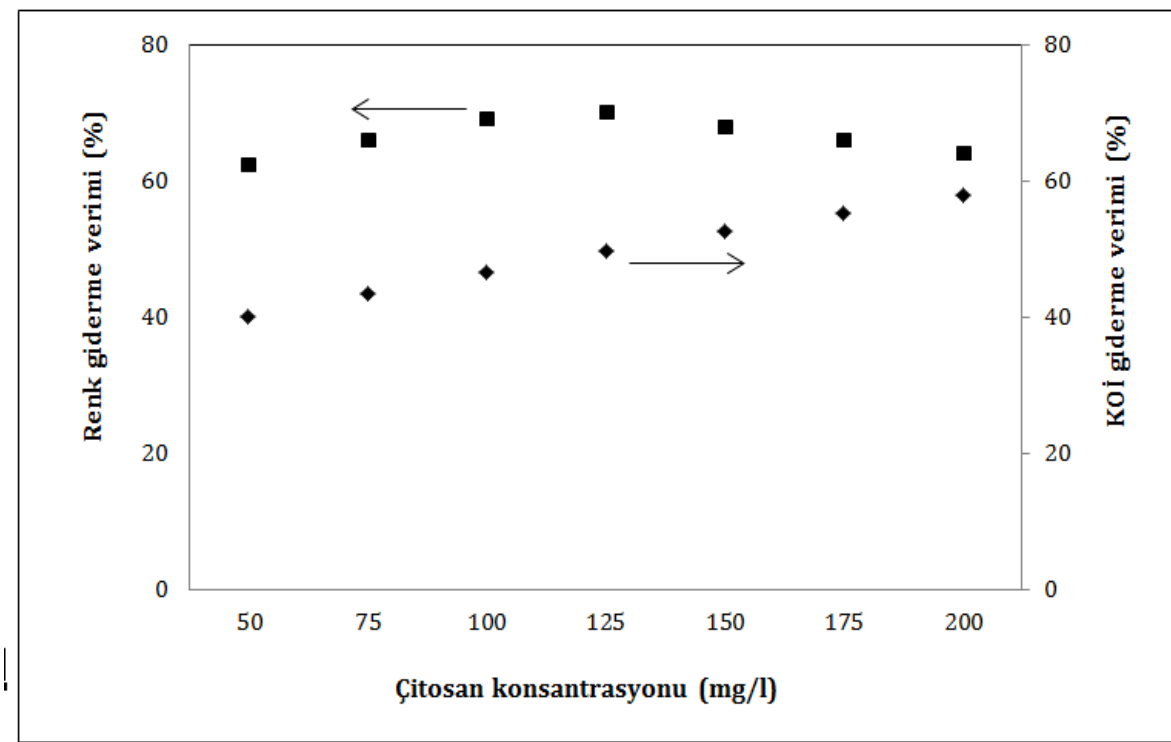

Şekil 7. Renk ve KOİ giderme veriminin çitosan konsantrasyonuyla değişimi. (Boya konsantrasyonu:50 mg/l, çökeltim süresi: 90 dakika) (๘) Renk giderme verimi, (\$) KOI giderme verimi

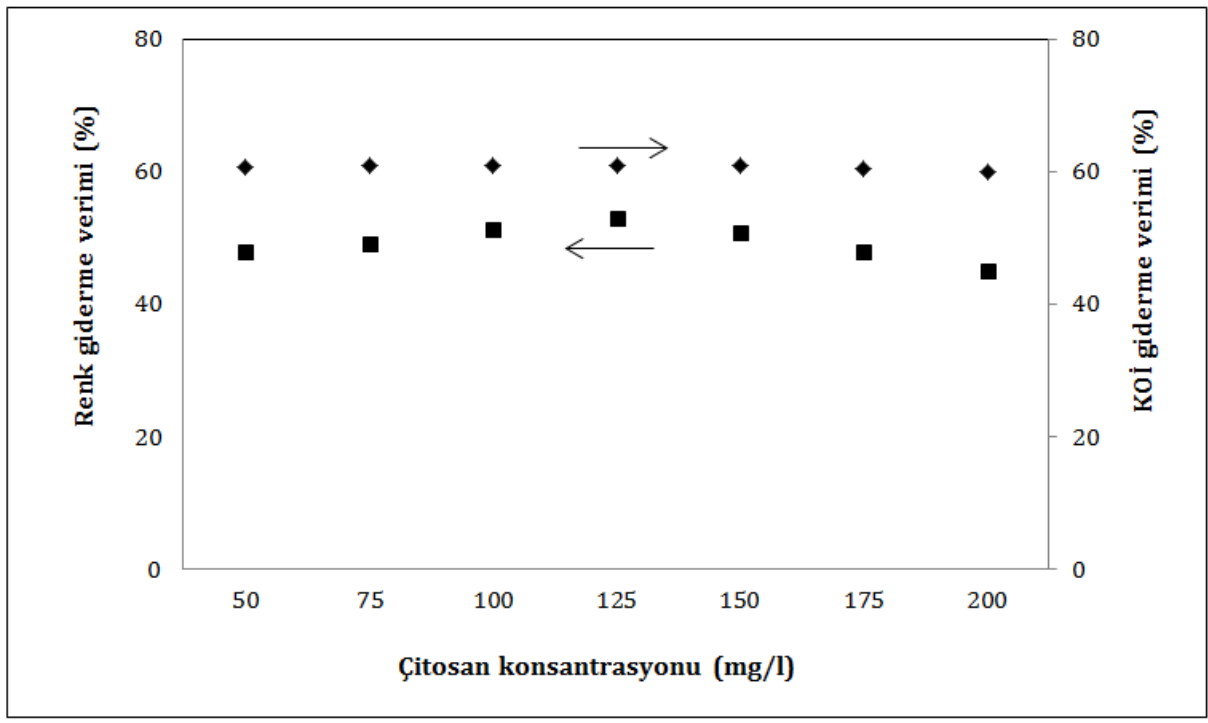

Şekil 8. Renk ve KOİ giderme veriminin çitosan konsantrasyonuyla değişimi. (Boya konsantrasyonu:200 mg/l, çökeltim süresi: 90 dakika) (๘) Renk giderme verimi, ( $\bullet$ KOİ giderme verimi 


\section{Sonuçlar}

Bu çalışmada, biyolojik bir polimer olan çitosanın koagülasyon-flokülasyon işlemi sırasında kullanımıyla boya içeren atıksulardan renk ve KOİ giderimi araștırılmıștır. Box-Wilson istatistiksel tasarım yöntemi, boyalı suların arıtımı için istatistiksel olarak güvenilir sonuçlar üretmek ve renk ile KOİ giderme verimliliklerini en iyi duruma getiren optimum koşulları saptamak için kullanılmıştır.

Box-Wilson istatistiksel tasarım metodu ile elde edilen cevap fonksiyonlarına Statistica programı uygulanarak hesaplamalar yapılmıştır. Renk giderimi için, deneylerde ölçülen renk değerleri ile programla hesaplanan renk değerleri arasındaki korelasyon katsayısı 0.944, KOİ giderimi için korelasyon katsayısı ise 0.942 olarak ölçülmüştür. Bu da hesaplanan değerler ile deneysel sonuçların birbirleri ile iyi bir uyum içinde olduğunu ve kullanılan yöntemin güvenilirliğini göstermektedir.

Renk giderme verimi artan çitosan konsantrasyonu ile artmış, 125 mg/l'nin üzerindeki çitosan konsantrasyonunda ise verim azalmaya başlamıştır. Boya konsantrasyonundaki artış ise renk giderimini olumsuz etkilemiştir. En yüksek renk giderme veriminin (\%70) elde edildiği optimum koşullar $50 \mathrm{mg} / \mathrm{l}$ boya konsantrasyonu, $125 \mathrm{mg} / \mathrm{l}$ çitosan konsantrasyonu ve 90 dakika çökelme süresidir.

KOİ giderme verimi ise artan boya ve çitosan konsantrasyonuyla artmaktadır. Çökelme süresindeki artış KOİ giderimi üzerinde çok etkili değildir. $200 \mathrm{mg} / \mathrm{l}$ boya konsantrasyonu, $200 \mathrm{mg} / \mathrm{l}$ çitosan konsantrasyonu ve 30 dakika çökelme süresinde elde edilen KOİ giderme verimi $\% 60$ olarak bulunmuştur.

\section{Kaynakça}

[1] Patel, H., Vashi, R.T. 2012. Removal of Congo Red Dye from its Aqueous Solution Using Natural Coagulants, Journal of Saudi Chemical Society, Cilt. 16, s. 131-136. DOI:10.1016/j.jscs.2010.12.003.

[2] Gomez, V., Larrechi, M.S., Callao, M.P., 2007. Kinetic and Adsorption Study of Acid Dye Removal using Activated Carbon, Chemosphere, Cilt. 69, s. 1151-1158. DOI: 10.1016/j.chemosphere.2007.03.0 76.

[3] Perkowski, J., Kos, L., Ledakowicz, S., (1996). Application of Ozone in Textile Wastewater Treatment, Ozone: Science \& Engineering, Cilt. 18, s. 73-85. DOI: 10.1080/01919519608547342.

[4] Szyguła, A., Guibala, E., Ruizb, M. and Sastrec, A.M. 2008. The Removal of Sulphonated Azo-Dyes by Coagulation with Chitosan, Colloids and Surfaces A: Physicochemical Engineering Aspects: Cilt. 330, s. 219-226. DOI: 10.1016/j.colsurfa.2008.08.001.

[5] Dos Santos, A.B., Cervantes, F.J., Van Lier, J.B. 2007. Review Paper on Current Technologies for Decolourisation of Textile Wastewaters: Perspectives for Anaerobic Biotechnology, Bioresource Technology, Cilt. 98, s. 2369-2385. DOI: 10.1016/j.biortech.2006.11.013.

[6] Lin S., Lo C. 1997. Fenton Process for Treatment Desizing Wastewater, Water Research, Cilt. $31(8)$, s. 2050 - 2056. DOI: 10.1016/S0043-1354(97)00024-9. 
E.O.Akdemir / Boyalı Suların Çitosan Koagülasyonu ile Arıtımında Box-Wilson İstatistiksel Tasarım Yönteminin Kullanılması

[7] Akdemir, E. 2012. A Statistical Experiment Design Approach for Decolorization of Textile Dyestuff by Coagulation with Chitosan, Fresenius Environmental Bulletin, Cilt. 21 (6), s. 1461-1467.

[8] Szygula, A. Guibal, E., Palacin, M, Ruiz, m., Sastre, A.M. 2009. Removal of an Anionic Dye (Acid Blue 92) by CoagulationFlocculation using Chitosan, Journal of Environmental Management, Cilt. 90(10), s. 29792986.

DOI: 10.1016/j.jenvman.2009.04.002.

[9] Asif, M.B., Majeed, N., Iftekhar, S., Habib, R. Fida, S., Tabraiz, S. 2016. Chemically Enhanced Primary Treatment of Textile Effluent using Alum Sludge and Chitosan, Desalination and Water Treatment, Cilt. 57(16), s. 7280-7286. DOI: 10.1080/19443994.2015.1015448.

[10] American Public Health Association, American Water Works Association, Water Pollution Control Federation. 1992. Standart Methods for the Examination of Water and Wastewater, 18th Edition, Washington.

[11] García, J. L., Lehocký, M., Humpolíček, P., Sáha, P. 2014. HaCaTKeratinocytes Response on Antimicrobial Atelocollagen Substrates: Extent of Cytotoxicity, Cell Viability and Proliferation, Journal of Functional Biomaterials, Cilt. 5, s. 43 -57. DOI: $10.3390 /$ jfb5020043.

[12] http://www.worlddyevariety.com /reactive-dyes/reactive-red195.html, (Erişim Tarihi: 21.01.2007).
[13] Guibal, E. 2004. Interactions of Metal Ions with Chitosan Based Sorbents: A Review, Separation and Purification Tecnology, Cilt. 38, s. 43-74. DOI: 10.1016/j.seppur.2003.10.004.

[14] Hassan, M.A.A, Li, T.P., Noor, Z.Z. 2009. Coagulation and Flocculation Treatment of Wastewater in Textile Industry using Chitosan, Journal of Chemical and Natural Resources Engineering, Cilt.4(1) s.43-53.

[15] Patel, H., Vashi, R.T. 2013. Comparison of Naturally Prepared Coagulants for Removal of COD and color from Textile Wastewater, Global NEST Journal, Cilt. 15(4), s. 522-528. 